\title{
DAUGIAKRITERINIŲ METODU TAIKYMAS OPTIMALIAM INVESTICINIAM PORTFELIUI SUDARYTI
}

\author{
Radvinė SKOBAITË*, Raimonda MARTINKUTĖ-KAULIENĖ \\ Vilniaus Gedimino technikos universitetas, Verslo vadybos fakultetas, \\ Finansu inžinerijos katedra, Saulètekio al. 11, LT-10223, Vilnius, Lietuva \\ "El.paštas radvinè.skobaite@stud.vgtu.lt
}

\begin{abstract}
Santrauka. Daugelis teorijų tyrinèdamos investicinių portfelių formavimą atsižvelgia ị istorinius finansiniu instrumentų duomenis. Tačiau, siekiant gauti didesnę grąžą reikalinga išsami analizè, todèl finansiniams instrumentams atrinkti, reikalingas kompleksiškas vertinimas. Straipsnyje investicinio portfelio sudarymui naudojami daugiakriterinai vertinimo metodai, kurie leidžia susisteminti visus reikalingus veiksnius ir atlikti kompleksini vertinimą. SAW ir TOPSIS metodai leidžia išvengti subjektyvumo, nereikalauja nustatyti nagrinėjamų veiksnių reikšmingumo koeficientų. Investicinio portfelio vertinimo modelis apima veiksnių sistemos sudarymą, daugiakriterio metodo pritaikymą, finansinių instrumentų vertinimą ir rangavimą analizuojamame kontekste. Šiuo atveju, SAW metodo atrinktos akcijos generuoja geresnius rezultatus, lygindami laukiamą pelningumą, riziką, variacijos koeficientą bei Šarpo rodiklị. Šio straipsnio tikslas - sudaryti optimalius investicinius portfelius, pritaikant daugiakriterius vertinimo metodus SAW ir TOPSIS. Straipsnyje taikyti šie tyrimo metodai: mokslinès literatūros analizè, sisteminimas, lyginimas, finansinių ataskaitų analizė, statistinių duomenų analizė, daugiakriteriniai metodai SAW ir TOPSIS, grafinis duomenų atvaizdavimas.
\end{abstract}

Reikšminiai žodžiai: investicinis portfelis, optimizavimas, SAW, TOPSIS, finansiniai instrumentai, atranka.

\section{Ivadas}

Kaip teigia Yufei et al. (2019) investicinių portfelių valdymas yra itin populiari ir patraukli veikla visame pasaulyje. Kadangi investavimas nèra lengvas procesas, jis dažnai reikalauja profesionalų pagalbos. Turint finansiniu žinių ir praktiniu ịgūdžiu yra galimybè sudaryti daugybę investiciniu portfelių ir jų variacijų, priklausomai nuo prisiimamo rizikos lygio, investavimo strategijos, siekiamos grąžos dydžio ir kt. Investavimas suteikia galimybę laisvas lešas panaudoti jų vertės didinimui t. y. gauti pelną priklausomai nuo prisiimtos rizikos. Investavimo galimybių yra daug ir ịvairių, o investavimo rinka tampa vis atviresnè ir globalesnè. Vis didesnès galimybės investuoti verčia atidžiau rinktis investavimo būdus ir finansinius aktyvus. Reikia ịvertinti ne tik vietinius, bet ir nacionalinius ekonominius veiksnius, siekiant numatyti galimus pokyčius globalioje rinkoje, kad būtų priimti teisingi investavimo sprendimai. Teorijoje vyrauja taisyklè - kuo didesnè rizika, tuo didesnis pelningumas, tačiau prisiimta didesné rizika gali atnešti ir didesnius nuostolius, todèl siekiant sukontroliuoti și aspektą svarbu tinkamai suformuoti investicinị portfeli t. y. ji optimizuoti. Rekomenduojama, kad investicinį portfeli sudarytų skirtingo pobūdžio finansiniai instrumentai. Investicinis portfelis dažniausiai atspindi investuotojo poreikius ir galimybes. Praktikoje, siekiant sudaryti optimalu investicini portfeli, portfelio valdytojui rekomenduojama nuspręsti kokiam laikotarpiui jis planuoja investuoti, kokią sumą gali skirti, koks investavimo tikslas ir koks yra toleruojamas rizikos lygis, siekiant išlaikyti optimalu investicinį portfeli (Nhi et al., 2019). Sunkiausias etapas investavimo procese - aktyvų atranka, kuri leistų pasiekti užsibrèžtus tikslus ir lūkesčius. Iš to ir kyla šio straipsnio problema - Baltijos akcijų rinka nèra viena iš labiausiai išnagrinètu rinkų, taip pat nèra konkrečios informacijos apie įmonių akcijas ị kurias būtų galima atsižvelgti investuotojui, renkantis akcijas. Todèl verta daryti išsamią analizę, remtis daugiakriteriniais metodais, siekiant išsiaiškinti, kurios bendroves, generuoja didžiausią grą̌ą ir iš kokių bendrovių akcijų turètų būti sudarytas optimalus investicinis portfelis.

Tyrimo objektas - optimalus investicinis portfelis.

Šio straipsnio tikslas - sudaryti optimalius investicinius portfelius, pritaikant daugiakriterius vertinimo metodus SAW ir TOPSIS finansiniams instrumentams parinkti. 
Siekiant išsikelto tikslo formuluojami šie uždaviniai:

1. Išanalizuoti investicinio portfelio teorinius aspektus;

2. Pateikti daugiakriterinio vertinimo metodų SAW, TOPSIS teorini pagrindimą;

3. Sudaryti optimalius investicinius portfelius remiantis SAW, TOPSIS metodais;

4. Ivertinti sudarytus optimalius portfelius.

Tikslo igyvendinimui atliekama mokslinès literatūros analizè, sisteminimas, lyginimas, finansinių ataskaitų analizè, statistinių duomenų analizè, daugiakriteriniai metodai SAW, TOPSIS, grafinis duomenų atvaizdavimas.

Straipsnio struktūra: pirmoje darbo dalyje analizuojama investicinio portfelio samprata bei sudarymo procesas antroje darbo dalyje aprašomi daugiakriteriniai vertinimo metodai SAW ir TOPSIS. Trečioje - aptariamas optimalaus investicinio portfelio sudarymas, išskiriamos akcijos sudarysiančios portfelius, parenkami vertinimo kriterijai, galiausiai įvertinami sudaryti investiciniai portfeliai, atliekamas SAW ir TOPSIS metodų rezultatų lyginimas.

\section{Optimalaus investicinio portfelio teorinis pagrindimas}

Sudarant optimalų investicinị portfelị ir nagrinejjant jo savybes reikalingas tikslus šios sąvokos apibrěžimas. Tikimybiniu aspektu portfelis - tai atsitiktinis dydis, gaunamas, kaip atsitiktinių dydžių - atskirų investicijų suma (Springer, 2011). Šis straipsnis remiasi dviem portfelio apibrèžimais: portfelio plačiaja prasme - kaip turto rinkinys ir portfelio siaurają (matematine) prasme - kaip atsitiktinis dydis. Kadangi šiame darbe analizuojamas investicinis portfelis, tai pagal anksčiau pateiktus portfelio termino apibrėžimus, finansinių priemonių portfelį reikètų suprasti kaip finansinių priemonių rinkinį. Šios sąvokos teisinį apibrèžimą galima rasti ir Lietuvos Respublikos finansinių priemonių rinkų ịstatyme, kuriame finansinių priemonių portfelis apibūdinamas kaip investuotojo turimų finansinių priemonių rinkinys (Lietuvos Respublikos finansinių priemonių rinkų įstatymas, 2007). Taip pat pagal Lietuvos Respublikos finansinių priemonių rinkų ịstatymą (2007) išskiriamos šios finansinès priemonès:

1. Perleidžiamieji vertybiniai popieriai;

2. Pinigų rinkos priemonès - iždo vekseliai, indèlio sertifikatai, bendrovių išleisti trumpalaikiai skoliniai įsipareigojimai ir kita, išskyrus mokejjimo priemones;

3. Kolektyvinio investavimo subjektų vertybiniai popieriai;

4. Su vertybiniais popieriais, valiutomis, palūkanų normomis ar pajamingumu susieti pasirinkimo, ateities, apsikeitimo, išankstiniai palūkanų normos sandoriai ir kiti išvestiniai susitarimai, taip pat kitos išvestinès priemonès, finansiniai indeksai ir priemonès;

5. Su biržos prekėmis susieti pasirinkimo, ateities, apsikeitimo, išankstiniai palūkanų normos sandoriai ir kiti išvestiniai susitarimai;

6. Kredito rizikos perkèlimo išvestinès priemonès;

7. Finansiniai susitarimai dèl skirtumų;

8. Su klimato sąlygų pokyčiais, krovinių gabenimo įkainiais, taršos emisijomis, infliacijos rodikliais ar kitais oficialiais ekonominès statistikos rodikliais susieti pasirinkimo, ateities, apsikeitimo, išankstiniai palūkanų normos sandoriai ir kiti išvestiniai susitarimai.

Dar viena svarbi sąvoka, kuri portfelio teorijoje, galima sakyti, yra pagrindinis tyrimo objektas ir su kuria vertetų susipažinti kalbant apie portfelio sudarymą yra optimizavimas. Investicinio portfelio optimizavimas yra vienas iš svarbiausių investuotojo tikslų. Jeigu tradiciškai portfelio sudarymas buvo nesisteminio, atsitiktinio ir intuityvaus pobūdžio, tai šiuolaikinio požiūrio užduotimi tapo optimalaus portfelio sudarymas. Optimalus portfelis - tai pagal tam tikrus kriterijus parinktas geriausias galimas portfelis (Nhi et al., 2019). Reikètų pabrěžti, kad optimalaus portfelio parinkimas prasmingas tik tam tikru laikotarpiu. Optimalų portfeli reikia vis atnaujinti, nes laikui bėgant gali stipriai pasikeisti investuotojo tikslai, situacija rinkoje ir kitos sąlygos.

Dažniausiai investicinị portfelị sudaro tam tikri finansiniai instrumentai su skirtingu rizikos bei pajamingumo lygiu. Tokiu būdu portfelis yra tarsi instrumentas, kurio pagalba esant priimtinam rizikos lygiui investuotojas užsitikrina laukiamą pelningumą. Praktikoje matyti, kad investuotojai beveik niekada neinvestuoja ị vieną finansinị instrumentą. Aišku, kuo mažiau vertybinių popierių yra portfelyje, tuo jis rizikingesnis. Jei portfelyje yra daugiau finansinių priemonių, tai didesnè tikimybè, kad sumažèjus vienų priemonių kainoms, kitų priemonių išaugusios kainos kompensuos patiriamus praradimus, t. y. bendra portfelio rinkos vertẻ labai nesumažès. Investuodamas $\mathfrak{i}$ platesnị ir įvairesnị finansinių instrumentų portfelį, investuotojas diversifikuoja savo investicijas, taip išskaidydmas riziką ir ją sumažindamas. Kadangi tikètinas investicijų pelningumas ir rizika yra tarpusavyje glaudžiai susiję, tai išskaidant riziką, t. y. ją sumažinant, sumažinama ir galimybe daug uždirbti. Kuo ịvairesnis investicinis portfelis, tuo mažiau jo rinkos vertė reaguoja ị trumpalaikius rinkos svyravimus. Investuotojams pasirinkti tinkamiausią momentą investicijoms ir nustatyti investicijų sudėti ir apimtį padeda finansinè ir ekonominè informacija. Finansų institucijos ir finansų analitikai seka ekonomikos pokyčius, prognozuoja jų poveikị finansų rinkai ir finansinių instrumentų kainoms. Taip pat žiūrima ì bendrajị rinkos stabilumą, likvidumą, šakos būklę, naudojamas technologijas ir t. t. Brazausko (2014), nuomone, formuojant investicinị portfelị yra būtina atsižvelgti ị:

1. Rizikos lygi (investicijų saugumą);

2. Pajamingumą; 
3. Likvidumą;

4. Aplinkos poveikị.

Javid ir Tafti (2019) teigia, kad optimalų investicini portfelį turètų sudarytị: $50 \%$ saugios priemonès paprastai valstybiu obligacijos. Kiti $50 \%$ nukreipiami i rizikingas turto klases: $25 \%$ akcijoms, $12.5 \%$ nekilnojamajam turtui ir $12.5 \%$ žaliavoms ar auksui. Pusé sudaryto investicinio portfelio generuotu pastovias pajamas iš obligacijų mokamų palūkanų, kita dalis investuojant ilgesniam laikotarpiui uždirbtų daugiau iš akcijų pelno augimo, mokamų dividendų, nekilnojamojo turto nuomos pajamų, turto vertès padidèjimo, o nedidelè dalis apie $10 \%$ skirta auksui - apsaugotų nuo didelès infliacijos. Iš to seka, portfelio formavimo proceso svarba. Daugelis mokslininkų (Huang et al., 2012; Teresiené, 2009; Javid ir Tafti, 2019) sutinka, kad yra trys investicinio portfelio formavimo etapai, kurie padeda investuotojui suformuoti optimalų vertybiniu popieriu portfelį (žr. 1 paveikslą).

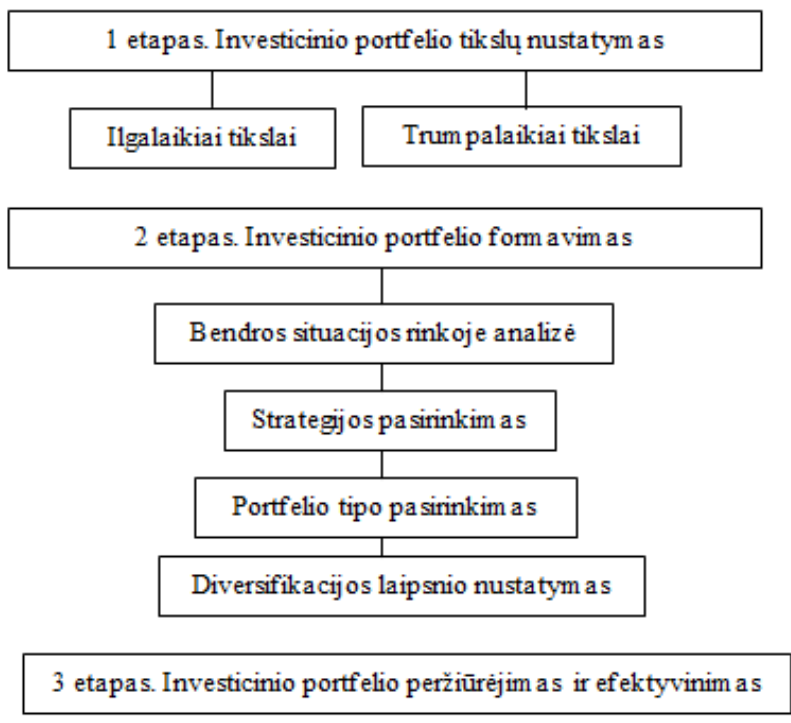

1 paveikslas. Investicinio portfelio formavimo procesas (sudaryta autorès, remiantis Brazauskas, 2014)

Atsižvelgiant $\mathfrak{i}$ išvardintus tris pagrindinius etapus, svarbu tinkamai apskaičiuoti skirtingų portfelių sudetị, pelną ir riziką, taip pat verta atkreipti dèmesị ir ị rinkos pokyčius. Pasak Basilio et al. (2018), vertybinių popieriu portfelio siekiamos grąžos garantas - įvertintos investavimo galimybès, parengtas tinkamas planas bei sudaryta investavimo strategija. Optimalaus investicinio portfelio valdymas gali būti aktyvus ir pasyvus, tačiau dažniausiai pasirenkamos abi strategijos. Kai tik yra sudaromas investicinis portfelis, tuo pačių metu finansinių instrumentu kontrolè, priežiūra ir naujų galimybių paieška tęsiasi (Stanujkic et al., 2017). Šiuolaikinès portfelio teorijos, kitaip dar vadinamos šiuolaikinės investicijų valdymo teorijos, pradininku yra laikomas Harry Markowitz, $1952 \mathrm{~m}$. paskelbęs straipsni „Investicinio portfelio parinkimas“. Tại buvo naujo tipo investicijų tyrimo ir analizès pradžia. H. Markowitz pirmą kartą savo darbe pavartojo tokius terminus, kaip akcijų portfelio rizika ir portfelio diversifikacija. Markowitz (1952) ir Sharpe (1964) pasiūlytose, investicinio portfelio teorijose naudojami du svarbiausi rodikliai - rizikos lygis ir laukiamas pelningumas. Šie du rodikliai dažniausiai apskaičiuojami naudojant istorinius duomenis. Markowitz siūlo pelningumą apskaičiuoti aritmẹtiniu grąžos vidurkiu, o rizikos lygi - remiantis praejjusių laikotarpių grąžos standartiniais nuokrypiais ir dispersijomis (Stanujkic et al., 2017). Sharpe siūlo rizikos ivertinimui papildomai naudoti ir indekso pelningumą. Kimiagari ir Amini (2007), Kheradyar et al. (2011) ir Brazauskas (2014) rizikos lygiui apskaičiuoti naudoja ne dispersiją, o kitokius vertinimo metodus, tokius kaip: MAD (angl. mean absoliute deviation), CVaR (angl. conditional value at risk), GMD (angl. gini's mean difference), VaR (angl. value ar risk) ir kitus. Beveik visi šie metodai neivertina investuotojams svarbių fundamentalių akcijos rodiklių ir remiasi tik akcijos kainos kitimu. Remiantis šiais trūkumais, Keršulienė (2017) pataria naudoti daugiakriterinius sprendimo prièmimo metodus. Šie metodai naudojami sudètiniams sprendimams sudaryti, kai yra naudojami ịvairūs rodikliai ir veiksniai, lemiantys akcijos patrauklumą investuotojui pagal laukiamą grą̌zą.

Ishizaka ir Nemery (2013), atliktas tyrimas parodè, kad daugiakriteriniai sprendimu prièmimo metodai dažniausiai naudojami investicinio portfelio analizei. Samaras et al. (2008), teigia, jog taikant daugiakriterinius metodus turi būti nustatoma, kokio tipo, maksimizuojamo ar minimizuojamo yra kiekvienas veiksnys ar rodiklis. Minimizuojamujų rodiklių geriausios reikšmès - mažiausios, ir geriausios maksimizuojamujų rodiklių reikšmès atvirkščiai - didžiausios. Daugiakriterinių vertinimo metodų kriterijai dažniausiai apjungia normalizuotas $\left(r_{i j}\right)$ reikšmes ir šių rodiklių svorius i vieną bendrą dydį, kitaip dar vadinamu - metodo kriterijumi. Dauguma daugiakriterinių metodų taiko rodiklių reikšmių (pradinių duomenų) skirtingą normalizavimą, transformavimą. 


\section{Daugiakriteriniai vertinimo metodai SAW ir TOPSIS}

Mokslininkai (Jayasekara et al., 2019) siūlo ịvairius daugiakriterinius metodus, tokius kaip: AHP, COPRAS, VIKOR, WESPAS, MOORA, TOPSIS (technique for the order preference by similaryti to ideal solution), SAW (simple additive weighting), EDAS ir t. t. Çalık et al. (2019), lygindami MOORA ir SAW metodụ rezultatus nustate, jog SAW daugiakriterinis metodas leidžia tiksliau ịvertinti rezultatus. Lyginant VIKOR ir TOPSIS metodus Calik (2019) nustate, kad TOPSIS leidžia nustatyti ne tik rezultatus artimus teigiamam idealiam sprendimui, bet ir iš neigiamos pusès (rezultatus artimus neigiamam idealiam sprendimui).

Visi šie mokslininkų nagrinėjami daugiakrteriniai vertinimo metodai skiriasi pagal savo sudètingumą. Žinomiausias ir dažniausiai taikomas - SAW metodas (Kalayci et al., 2019). SAW metodo kriterijus $S_{j}$, išreiškia rodikliụ reikšmių ir svorių jungimą į vieną dydį. Šiuo metodu gaunama visų rodiklių normalizuotų reikšmių suma $S_{j}$ kiekvienam $j$-ajam objektui. Ji gaunama remiantis 1 formule (Basilio et al., 2018).

$$
S_{j}=\sum_{i=1}^{m} w_{i} r_{i j}^{\prime},
$$

čia: $\mathrm{w}-i$-tojo rodiklio svoris; $r_{i j}^{\prime}-i$-tojo rodiklio normalizuota reikšmé $j$-ajam objektui.

Siekiant gauti tikslius rezultatus, būtinas pradinių duomenų normalizavimas, kuris prasideda pirmiausiai nuo neigiamų rodiklio reikšmių panaikinimo (žr. 2 formulę).

$$
\hat{r}_{i j}=r_{i j}+\left|\min _{j} r_{i j}\right|+1,
$$

čia: $r_{i j}-i$-tojo rodiklio reikšmè.

SAW metodo būtina taikymo sąlyga - išankstinis rodiklių tipo nustatymas, ar tai maksimizuojamas ar minimizuojamas rodiklis, tik tuomet yra atliekamas pradinių duomenų normalizavimas, pagal 3-4 formules.

$$
\begin{array}{r}
r_{i j}^{\prime}=\frac{r_{i j}}{\max _{j} r_{i j}}, \\
r_{i j}^{\prime}=\frac{\min _{j} r_{i j}}{r_{i j}},
\end{array}
$$

čia: $r_{i j}^{\prime}-i$-tojo rodiklio normalizuota reikšmé $j$-ajam objektui; $r_{i j}-i$-tojo rodiklio reikšmè.

SAW metodo skaičiavimai rodo, kad $S_{i j}$ kriterijaus taikymas yra tikslingas pradiniu vertinimo etapu, tačiau šio metodo rezultatai - objektų rangavimas, mažai kuo skiriasi nuo sudètingų matematinių, statistinių metodų (Koedijk et al., 2019). SAW metodo skaičiavimas yra paprastas, ji galima atlikti be sudètingų kompiuterinių programų. Tačiau jis turi specifinių trūkumų (Freedman ir Nutting, 2015):

1. Visos kriterijų $r_{i}$ reikšmès turi būti maksimalios.

2. Visos kriterijų reikšmès $r_{i}$ turi būti teigiamos.

3. SAW pateikiami ịverčiai ne visada atspindi realią situaciją. Gautas rezultatas gali būti nelogiškas, nes vieno konkretaus kriterijaus reikšmès labai skiriasi nuo kitų kriterijų.

Kitas nesudètingas daugiakriterinių vertinimo metodu yra TOPSIS. Šis metodas buvo sukurtas 1981 metais Hwang ir Yoon mokslininkų. Tai alternatyvų prioriteto nustatymo teorija, kuri sako, jog geriausia alternatyva yra mažiausiai nutolusi nuo teigiamo idealus sprendimo ir labiausiai nutolusio nuo neigiamo idealaus sprendimo (Ghorabaee et al., 2017). Topsis metodo teorija dar vadinama variantu prioriteto nustatymo pagal artumo idealiam taškui metodas. Teigiamas - idealus sprendimas yra sprendimas, maksimaliai padidinantis maksimizuojančius kriterijus ir sumažina minimizuojančius kriterijus, tuo tarpu neigiamas idealus sprendimas padidina minimizuojančius kriterijus ir sumažinantis maksimizuojančius kriterijus (Žilinskij ir Rutkauskas, 2012). Trumpai tariant, teigiamas - idealus sprendimas yra sudarytas iš visų geriausių kriterijų, kuriais galima pasiekti pagal maksimumą, kadangi neigiamą idealų sprendimą sudaro visi minimizuojantys kriterijai. TOPSIS metodas naudoja vektorinę normalizaciją (Calik, 2019):

$$
n_{i j}=\frac{x_{i j}}{\sqrt{\sum_{i=1}^{m} x_{i j}^{2}}},
$$

čia: $n_{i j}-i$-tojo rodiklio normalizuota $j$-tojo objekto reikšmè.

Atlikus pradinių duomenų normalizaciją, sekantis žingsnis apskaičiuoti svertinę normalizuotą matricą, kuri reikalinga tolimesniems skaičiavimams (žr. 6 formulę). 


$$
v_{i j}=w_{j} n_{i j}
$$

čia: $w_{i}-i$-ojo kriterijaus svoris; $v_{i j}$ - svertinè normalizuota vertè.

Geriausi kriterijaus variantai $V^{+}$ir blogiausi variantai $V^{-}$skaičiuojami pagal 7-8 formules.

$$
\begin{gathered}
V^{+}=\left(v_{1}^{+}, v_{2}^{+}, \ldots, v_{n}^{+}\right)=\left(\left(\max _{i} \mid j \in I\right),\left(\min _{i} v_{i j} \mid j \in J\right)\right), \\
V^{-}=\left(v_{1}^{-}, v_{2}^{-}, \ldots, v_{n}^{-}\right)=\left(\left(\min _{i} v_{i j} \mid j \in I\right),\right.
\end{gathered}
$$

čia: $V^{+}-$teigiamas idealus sprendimas; $V^{-}$- neigiamas idealus sprendimas; $I$ - maksimizuojamų rodiklių aibė; $J-$ minimizuojanti rodiklių aibè.

Taip pat yra skaičiuojamas kiekvieno lyginamojo rodiklio bendras atstumas $S_{i}^{+}$iki geriausio varianto arba kitaip tariant iki teigiamo idealaus sprendimo ir $S_{i}^{-}$iki neigiamo idealaus sprendimo (žr. 9-10 formules).

$$
S_{i}^{+}=\sqrt{\sum_{j=1}^{n}\left(v_{i j}-v_{i}^{+}\right)^{2}},
$$

čia: $S_{i}^{+}-$teigiamas atstumas nuo idealaus varianto.

$$
S_{i}^{-}=\sqrt{\sum_{j=1}^{n}\left(v_{i j}-v_{i}^{-}\right)^{2}},
$$

čia: $S_{i}^{-}-$neigiamas atstumas nuo idealaus varianto.

Pagrindinis TOPSIS metodo kriterijus $P_{i}$ apskaičiuojamas pagal 11 formulę.

$$
P_{i}=\frac{S_{i}^{-}}{S_{i}^{-+S_{i}^{+}}},
$$

čia: $P_{i}$ - santykinis atstumas nuo idealaus varianto.

Pagal $P_{i}$ gautas reikšmes suranguojamos įmonių akcijos. Topsis indekso reikšmės svyruoja nuo 0 iki 1 (Chen, 2019). Kuo didesnė indekso reikšmė, tuo patrauklesnè akcija. Geriausią reikšmę atitinka didžiausia $P_{i}$ kriterijaus reikšmè. Lyginamuosius objektus reikia ranguoti mažejjančia tvarka.

Vienas iš svarbiausių daugiakriterinių metodų taikymo etapų yra pasirinktų kriterijų reikšmių nustatymas. Remiantis rekomendacijomis, nagrinejjamais tyrimais, moksline literatūra ir kitais informaciniais šaltiniais apskaičiuojamos kiekybinių kriterijų reikšmès, o kokybinių kriterijų reikšmès dažniausiai gaunamos taikant ekspertinius metodus. Kriterijų svoriams gauti, mokslininkai naudoja skirtingus vertinimo metodus. Žilinskij (2012) kriterijų svorius apskaičiuoja remiantis trijų praejjusių metų akcijos patrauklumo ir grąžos koreliacijos vidurkiu. Huang et al. (2012) pataria svorių dydžiams nustatyti atliki ekspertų apklausą. Kiti autoriai (Garcia et al., 2010) kriterijų svorius apskaičiuoja kiekybinius kriterijus išreiškę sumine pinigine išraiška arba paskirstant svorius visiems kriterijams vienodus.

\section{Optimalaus investicinio portfelio sudarymas}

Siekiant suformuoti optimalų investicinị portfelį, vertètų ne tik išsianalizuoti prieinamą informaciją, bet ir būti gerai apsisprendusiam, i kokius aktyvus investuoti geriausia. Investiciniai aktyvai pasižymi skirtingomis charakteristikomis, todèl siekdami savo tikslų turime nuspręsti, kurie aktyvai jums yra priimtiniausi. Viena iš aktyvų rūšių akcijos, tai viena iš populiariausių investavimo krypčių visame pasaulyje. Būtent dèl to, kad akcijos gali suteikti didžiausią potencialią grąžą tarp tradicinių investavimo priemonių (Betschinger, 2015). Jeigu ịmonè veikia pelningai, akcijų turètojams yra išmokami dividendai t. y. dalis kompanijos grynojo pelno. Tačiau, kai kurios imonès - nemoka dividendų, tokiu atveju investuotojai uždirba iš akcijų vertès pokyčio biržoje. Javid and Tafti (2019) teigia, kad akcijos yra žymiai rizikingesnès nei kiti aktyvai, bet ilguoju laikotarpiu generuoja didesnę grąžą. Taigi siekiant maksimalios grąžos, vertetų investicinį portfelị sudaryti iš akcijų. Sekantis etapas - léšų paskirstymas. Sudarant investicinị portfelị svarbu pasirinkti, kokią dalị lěšų investuotojas gali skirti investicijoms, kokia dalimi vertètų paskirstyti lèšas tarp aktyvų. Investavimo strategijos pasirinkimas yra atsakingas momentas, kadangi sẻkmingas jos pasirinkimas sąlygoja solidžią investicinę grąžą, kai tuo tarpu investavimo strategijos neturejjimas gali atnešti nemenkus nuostolius. Valdymo strategija priklauso ne tik nuo investuotojo žinių, patirties, gebejimų ir nuojautos, bet ir nuo emocijų. Apsisprendus dèl investicijų dydžio, strategijos ir aktyvų rūšies, atliekama akcijų 
atranka. Akcijų atranka gali būti atliekama remiantis daugiakriteriniais vertinimo metodais, kurie suranguos geriausias įmonių akcijas, pagal pasirinktus kriterijus.

Imonių akcijų analize remiasi fundamentaliais ir techniniais metodais, kurių tikslas - akcijų rinkoje svyruojančių kainų ir paklausos prognozès (Chen, 2019). Šių metodų rodikliai leidžia išanalizuoti ir įvertinti įmonès veiklos efektyvumą, skolos dydį, veiklos plètros intensyvumą ir kita. Vertinant akcijų patrauklumą, remiamasi fundamentaliosios analizès kriterijais. Mokslininkų siūlomi akcijų patrauklumo kriterijai pateikiami 1 lenteleje.

1 lentelè. Kriterijai investiciniam patrauklumui nustatyti. (sudaryta autorių, remiantis Kimiagari ir Amini, 2007; Samaras et al., 2008; Garcia et al., 2010; Kheradyar et al., 2011; Huang et al., 2012; Žilinskij ir Rutkauskas, 2012; Brazauskas, 2014)

\begin{tabular}{|c|c|}
\hline Autorius, metai & Kriterijai investiciniam patrauklumui nustatyti \\
\hline $\begin{array}{l}\text { Kimiagari ir } \\
\text { Amini } \\
(2007)\end{array}$ & $\begin{array}{l}\text { Akcijos kainos ir pelno, tenkančio vienai akcijai santykis (P/E), akcijos kainos ir buhalterinės vertès } \\
\text { santykis }(\mathrm{P} / \mathrm{B}) \text {, akcijos kainos ir pardavimo pajamų santykis }(\mathrm{P} / \mathrm{S}) \text {, isipareigojimų ir nuosavo kapitalo } \\
\text { santykis (D/E), turto grąža (ROA), nuosavo kapitalo grąža (ROE), dividendų išmokejimo rodiklis, } \\
\text { dividendų augimo rodiklis }\end{array}$ \\
\hline $\begin{array}{l}\text { Samaras et al. } \\
(2008)\end{array}$ & $\begin{array}{l}\text { Finansinės struktūros rodikliai: nusidėvėjimas/materialusis turtas, nuosavas kapitalas/skolos,apyvartinis } \\
\text { kapitalas/trumpalaikis turtas, įsipareigojimai/turtas. Valdymo efektyvumo rodikliai: turto apyvartumas, } \\
\text { nuosavo kapitalo apyvartumas, atsargų apyvartumas dienomis. Pelningumo rodikliai: turto pelningumas } \\
\text { prieš mokant mokesčius, grynasis nuosavo kapitalo pelningumas, bendrasis pelningumas, veiklos } \\
\text { pelningumas. Finansavimosi politikos rodikliai: likvidus turtas /pardavimai; likvidus turtas /ilgalaikiai } \\
\text { ìsipareigojimai, likvidus turtas /investicijos }\end{array}$ \\
\hline $\begin{array}{l}\text { Garcia et al. } \\
(2010)\end{array}$ & $\begin{array}{l}\text { Trumpalaikis turtas, visas turtas, nuosavas kapitalas, apyvarta, veiklos pelnas, pelnas prieš mokant } \\
\text { mokesčius, grynasis metų pelnas, turto grąža, nuosavo kapitalo grąža, bendrasis likvidumas }\end{array}$ \\
\hline $\begin{array}{l}\text { Kheradyar } \\
\text { et al. (2011) }\end{array}$ & $\begin{array}{l}\text { Dividendų pajamingumas (DY), akcijos pelningumas (EY), buhalterinės vertès ir rinkos vertès santykis } \\
\text { (M/M) }\end{array}$ \\
\hline $\begin{array}{l}\text { Huang et al. } \\
\text { (2012) }\end{array}$ & $\begin{array}{l}\text { Santykiniai rodikliai: akcijos kainos ir pelno, tenkančio vienai akcijai santykis }(\mathrm{P} / \mathrm{E}) \text {, akcijos kainos ir } \\
\text { buhalterinès vertės santykis (P/B), akcijos kainos ir pardavimo pajamų santykis (P/S). Pelningumo } \\
\text { rodikliai: (ROE), (ROA), (OPM), (NPM). Finansinio sverto rodikliai: įsipareigojimų ir nuosavo kapi- } \\
\text { talo santykis. Likvidumo rodikliai: bendrasis likvidumas. Efektyvumo rodikliai: atsargu apyvartumas, } \\
\text { gautinų sumų apyvartumas. Augimo rodikliai: veiklos pelno augimas, grynojo pelno augimas }\end{array}$ \\
\hline $\begin{array}{l}\text { Žilinskij ir } \\
\text { Rutkauskas } \\
(2012)\end{array}$ & $\begin{array}{l}\text { Akcijų kainos pokytis, įmonės apyvartos augimas, veiklos pelningumas, EBITDA pokytis, grynasis } \\
\text { pelningumas, turto pokytis, vidutinio nuosavo kapitalo grąžos pokytis, skolų ir nuosavo kapitalo } \\
\text { santykis, bendrasis likvidumas, akcijos kainos ir buhalterinės vertes santykis, akcijos kainos ir pelno } \\
\text { akcijai santykis, akcijų apyvartos pokytis, dividendinis pajamingumas, akcijos kainos pokyčio ir } \\
\text { apyvartos pokyčio skirtumas }\end{array}$ \\
\hline $\begin{array}{l}\text { Brazauskas } \\
(2014)\end{array}$ & $\begin{array}{l}\text { Pardavimo pajamų augimas, grynojo pelno augimas, grynasis pelningumas, ROE, skolinto ir nuosavo } \\
\text { kapitalo santykis, akcijos kainos ir buhalterinès vertès santykis, akcijos kainos ir trumpalaikio turto } \\
\text { santykis, akcijos kainos ir pelno tenkančio akcijai santykis, dividendinis pajamingumas }\end{array}$ \\
\hline
\end{tabular}

Mokslininkai siūlo gana panašius akcijų vertinimo kriterijus. Šiuos kriterijus galima suskirstyti į techninius, fundamentalius ir mišrius. Dauguma mokslininkų (Zhang et al., 2019), akcijų vertinimui naudoja mikroekonominius ir emitento specifinius veiksnius ir retai įtraukia makroekonomių veiksnių. Fundamentalioji analizė yra neatsiejama nuo visos ekonominès analizès, kuri analizuoja šalies politiką, jos stabilumą, mokesčius, palūkanų normą, valiutos kurso riziką, užsienio skolą, biudžeto deficitą, infrastruktūrą ir t. t.

Apibendrinant, galima teigti, kad dažniausiai vertybinių popierių atrankai naudojami finansiniai santykiniai rodikliai yra turto grąža, turto apyvartumas, skubus likvidumas, bendrasis likvidumas, akcijos kainos ir pelno akcijai santykis, kainos ir buhalterinès vertès santykis, skolos ir nuosavo kapitalo santykis, atsargų apyvartumas dienomis, investicijų grąža, dividendų pajamingumas. Būtent dèl šios priežasties ir buvo pasirinkti šeši akcijų vertinimo kriterijai, kurių pagalba bus atrinktos patraukliausios (su didžiausia grąža ir mažiausia rizika) akcijos (žr. 2 lentelę). Akcijų rizikingumui nustatyti skaičiuojamas standartinis nuokrypis (Calık, 2019):

$$
Q_{i}=\sqrt{\sum_{i=1}^{n}\left(r_{i}-\bar{r}\right)^{2} \times \mathrm{P}},
$$

čia: $r_{i}$ - laukiamas $i$-tosios akcijos pelningumas proc.; $r^{\prime}$-vidutinis laukiamas $i$-tosios akcijos pelningumas proc.; $\mathrm{P}$ - tikimybè, kad bus gautas laukiamas pelningumas.

Statistiškai, variacija parodo laukiamų pelningumų dispersiją aplink jų vidurkį. Kuo didesnè laukiamo pelningumo dispersija, tuo didesnè rizika, variacija ar standartinis nuokrypis. Todèl variacija traktuojama, kaip vertybinio popieriaus rizikos matas (Freedman ir Nutting, 2015).

Mokslininkai, specialistai nuolat stengiasi tobulinti, kurti naujus įmonių patrauklumo vertinimo metodus. Dalis prieš kelis dešimtmečius taikytų kriterijų, metodų, tokių kaip pelningumu pagrịsti finansiniai rodikliai yra vis dar plačiai naudojami, nes yra gerai žinomi, patikrinti, praktiški, paprasti ir nereikalaujantys didelių léšų bei 
papildomų žinių. Būtent todèl, nagrinèjami autoriai, rekomenduoja ịmonių patrauklumui nustatyti, apskaičiuoti populiariausius pelningumo rodiklius, kurie leidžia įvertinti įmonès finansinę būklę, juos palyginti su konkurentais ir pasirinkti tinkamiausią akciją.

2 lentelè. Pasirinktų kriterijų sąrašas (sudaryta autorių, remiantis Nasdaq, 2019)

\begin{tabular}{|l|l|l|c|}
\hline Tipas & \multicolumn{1}{|c|}{ Kriterijus } & \multicolumn{1}{|c|}{ Apskaičiavimas } & \multicolumn{1}{|c|}{} \\
\hline Max & Pardavimo augimas & $\begin{array}{l}\text { (Pardavimai n metais - pardavimai n-1 metais ) / pardavimai n-1 } \\
\text { metais }\end{array}$ & $(13)$ \\
\hline Max & Dividendinis pajamingumas & Išmokèta dividendų suma / akcijos kaina & $(14)$ \\
\hline Max & Akcijos pelningumas & (Akcijos pardavimo kaina - pirkimo kaina) / pirkimo kaina & $(15)$ \\
\hline Max & $\begin{array}{l}\text { Akcijos kainos ir pelno, } \\
\text { tenkančio akcijai santykis (P/E) }\end{array}$ & Akcijos kaina/akcijos buhalterinè verte & $(16)$ \\
\hline Max & Grynasis pelningumas & Grynasis pelnas/pardavimai & $(17)$ \\
\hline Max & Nuosavo kapitalo grąža (ROE) & Grynasis pelnas/nuosavas kapitalas & $(18)$ \\
\hline
\end{tabular}

Optimalus investicinis portfelis sudaromas iš įmonių akcijų, kurios kotiruojamos Nasdaq OMX Baltic vertybinių popierių biržoje (Baltijos šalių vertybinių popierių birža, 2019). Atrinktos 33 įmonių akcijos. Atmestos, tos įmonès, kurių finansinių ataskaitų nèra galimybès gauti, bei kurių akcijomis pradèta prekiauti ankščiau nei 2008 metais. İmonių sąrašas pateikiamas 3 lentelèje.

3 lentelè. Pasirinktų ịmonių sąrašas (sudaryta autorių remiantis Nasdaq, 2019)

\begin{tabular}{|l|l|}
\hline \multicolumn{1}{|c|}{ Pramonės šaka } & \multicolumn{1}{c|}{ Imonė } \\
\hline Paslaugų sektorius & $\begin{array}{l}\text { AS Tallinna Kaubamaja grupp, AB Šiauliu bankas, AS Arco Vara, AS Ekspress Grupp, } \\
\text { AS EfTEN Real Estate Fund III, AS LHV Group, AB Novaturas, AS Pro Kapital Grupp, } \\
\text { AS Tallink Grupp, AS Tallinna Sadam }\end{array}$ \\
\hline Komunalinės paslaugos & AS Tallina Vesi, AB Ignitis gamyba, AB Energijos skirstymo operatorius \\
\hline Pramonės sektorius & $\begin{array}{l}\text { AB Klaipèdos nafta, AB Panevėžio statybos trestas, AS Merko Ehitus, AS Nordecon, } \\
\text { AS Harju Elekter, AB Grigeo, AS SAF Technika }\end{array}$ \\
\hline Sveikatos priežiūros & AS Grindeks, AS Olainfarm \\
\hline Telekomunikacijos sektorius & AB Telia Lietuva \\
\hline Plataus vartojimo prekės & $\begin{array}{l}\text { AB Pieno žvaigždės, AB Rokiškio sūris, AB Vilkyškių pieninė, AS Silvano Fashion } \\
\text { group, AB AUGA group, AS Baltika, AB Apranga, AS HansaMatrix, AS Linas Agro } \\
\text { Group, AS PRFoods }\end{array}$ \\
\hline
\end{tabular}

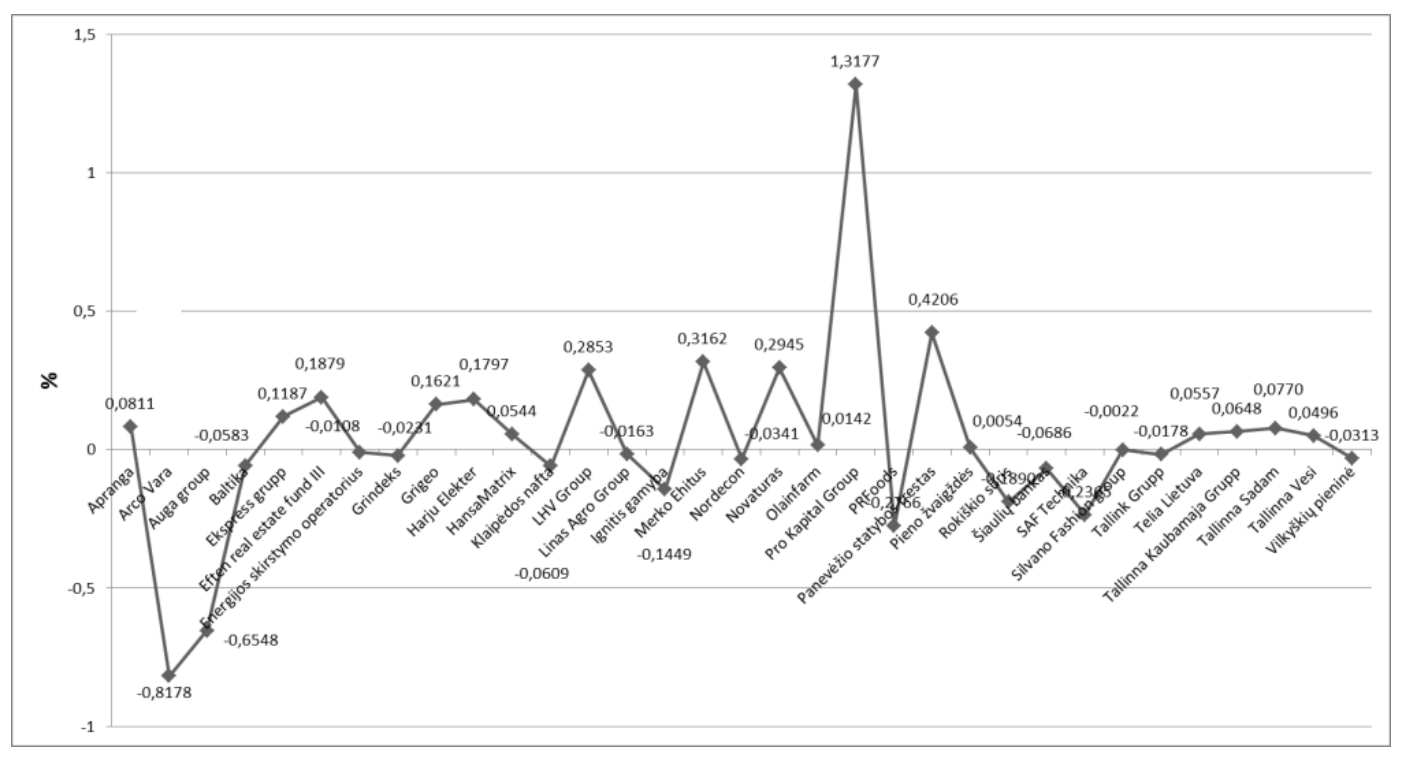

2 paveikslas. Pardavimų augimų vidurkiai 2008-2018 metų (sudaryta autorių) 
Pasirinktos įmonės išskirstytos pagal pramonės šakas. Iš 3 lentelès galima matyti, kad daugiausiai pasirinktų įmonių priklauso paslaugų sektoriui, kuris pasak Brazausko (2014) generuoja didžiausius pelnus pastaruosius metus. Pagal pasirinktus šešis kriterijus atlikta įmonių analizè. Analizuojami 2008-2018 metų duomenys ir išvedami vidurkiai. 2 paveiksle pateikti pardavimų augimai.

Pardavimų augimai apskaičiuojami pagal 12 formulę. Iš gautų rezultatų matyti, kad aukščiausi pardavimų augimai pastaruosius 10 metų buvo Pro Kapital Group įmoneje, didejjo net $131 \%$. Prasčiausias pardavimų augimas matomas Arco Vara įmoneje - matomas vidutinis smukimas $81 \%$.

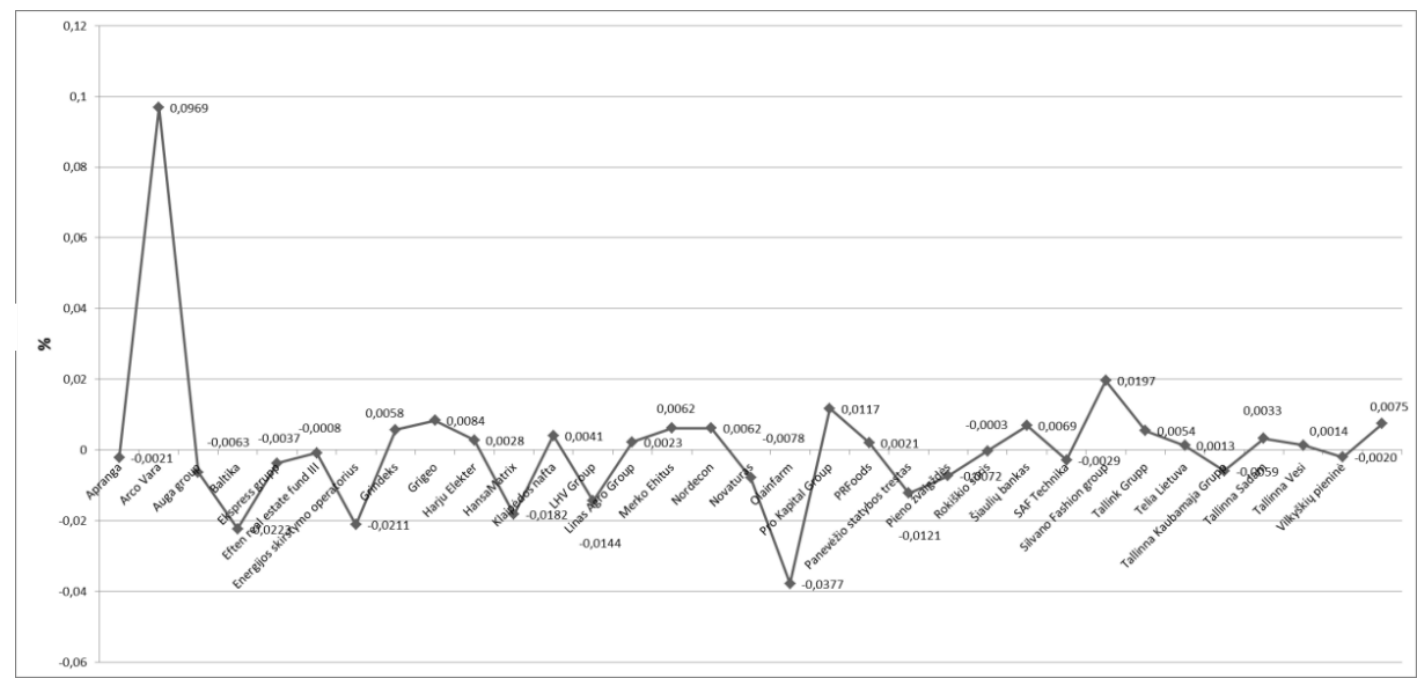

3 paveikslas. Akcijų pelningumo 2008-2018 metų vidurkis (sudaryta autorių)

Akcijų pelningumas apskaičiuojamas pagal 13 formulę (žr. 3 lentelę). Iš visų 33 ịmonių labiausiai išsiskyrẻ Ignitis gamyba ịmonès akcijų pelningumo vidurkis, kuris siekė net 12 eurų vienai akcijai. 3 paveiksle ši ịmonė neatsispindi, kadangi gauti rezultatai labai išsiskiria nuo kitų įmonių akcijų pelningumų. Aukštus pelningumus taip pat galime matyti ir iš Arca Vara (0,1 Eur) ir iš SAF Technika (0,02 Eur) akcijų. Iš paveikslo matyti, kad daugiau nei puse nagrinejjamų ịmonių akcijų pelningumas yra neigiamas. Didžiausias neigiamas pelningumas priklauso Novaturo akcijoms - 0,3 Eur.

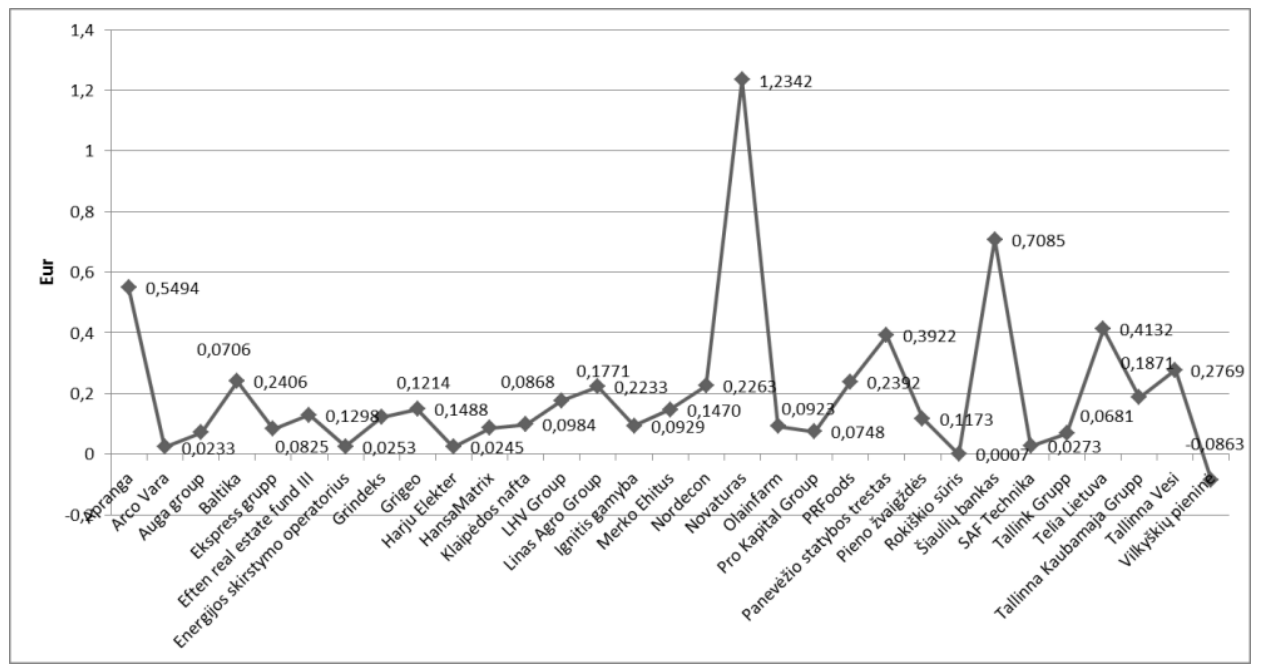

4 paveikslas. Nuosavo kapitalo grąžos vidurkis 2015-2018 metų (sudaryta autorių)

Nuosavo kapitalo pelningumas ROE, leidžia paskaičiuoti kiek efektyviai yra panaudojami investuoti pinigai, turtas. ROE rodiklis parodo kiek kiekvienam nuosavo kapitalo eurui tenka grynojo pelno. Kuo nuosavo kapitalo grąža didesnè, tuo efektyvesnè įmonès veikla ir tuo daugiau pelno ji uždirba investuotojams (Kalayci et al., 2019). Investuotojai nusistato, kokios grąžos jie siekia, o būtent ROE rodiklis ir leidžia matyti realius įmonès veiklos rezultatus ir lyginti juos su siekiama grąža. Tačiau ROE rodiklis labai priklauso nuo nuosavybès dydžio ịmonès turte bei nuo įmonès kapitalo struktūros. Iš 4 paveikslo matyti trisdešimt trijų įmonių ROE rodiklių reikšmes. Paveiksle nėra pateiktos Silvano Fashion group ir Tallinna Sadam įmonių rezultatai, kadangi šie labai išsišoksta. 
Tallinna Sadam įmonės reikšmė didžiausia (8,267 Eur) iš visų 33 nagrinėjamų įmonių, o Silvano Fashion group mažiausia (minus 4,568 Eur). Gerus rezultatus taip pat rodo ir Apranga, Novaturas, Šiaulių bankas bei Telia Lietuva.

Pradinis įmonių akcijų atrinkimas atliekamas norint išvengti nelikvidžių, problemų turinčių, nuostolingų immonių. Teorija ir praktika byloja, kad dažniausiai kainos mažejja tų akcijų, kurių kainos pakilimo momentu augo greičiausiai. Taigi būtent todèl yra svarbu ne tik atsižvelgti i akcijos kainą, jos augimą, bet ir išanalizuoti įmonès fundamentalios analizès kriterijus, kurie leidžia įvertinti įmonès padèti ir jos patrauklumą investuotojams. Investuotojas pats nusprendžia, kokius kriterijus naudos akcijų patrauklumui nustatyti. Yra galimybe rinktis tarp techninių, fundamentalių indikatorių, atliktų prognozių ar rekomendacijų. Pasiriktų kriterijų svoriai taip pat priklauso nuo investuotojo tikslų, jeigu pasirinktume vienodus kriterijus tačiau nustatytume skirtingus svorius, tai šių portfelių sudètis gali skirtis.

\section{Optimalaus investicinio portfelio vertinimas}

Tyrimui atlikti sudaromi du optimalūs investiciniai portfeliai, remiantis daugiakriteriniais vertinimo metodais - SAW ir TOPSIS. Investiciniam portfeliui sudaryti, pasirinktos 33 įmonių akcijos (žr. 3 lentelę), kurios yra kotiruojamos Nasdaq Baltijos biržoje. Tyrimui atlikti naudojami 2008-2018 metų įmonių duomenys. Iš susistemintų duomenų apskaičiuojami pasirinktų kriterijų rezultatai. Remiantis moksline literatūra ir mokslininkų atliktais tyrimais pasirinkti šeši kriterijai: pardavimo augimas, dividendų pajamingumas, akcijos pelningumas, akcijos kainos ir pelno, tenkančio akcijai santykis (P/E), grynasis pelningumas, nuosavo kapitalo grąža (ROE) (žr. 2 lentelę). Pirmasis investicinis portfelis sudaromas remiantis SAW metodo įmonių atrankos būdu. Gauti rezultatai pateikiami 4 lentelèje.

4 lentelè. Atrinktos akcijos pagal SAW metodą (sudaryta autorių)

\begin{tabular}{|l|c|c|}
\hline \multicolumn{1}{|c|}{ Akcijos } & $\mathrm{S}_{\mathrm{j}}$ & Rangai \\
\hline Apranga & 0,442526 & 8 \\
\hline $\begin{array}{l}\text { Energijos skirstymo } \\
\text { operatorius }\end{array}$ & 0,508166 & 4 \\
\hline Klaipėdos nafta & 0,512307 & 3 \\
\hline Ignitis gamyba & 0,648449 & 1 \\
\hline Novaturas & 0,41754 & 9 \\
\hline Pro Kapital Group & 0,470058 & 5 \\
\hline Panevėžio statybos trestas & 0,408675 & 10 \\
\hline Telia Lietuva & 0,45762 & 6 \\
\hline Tallinna Kaubamaja Grupp & 0,453439 & 7 \\
\hline Tallinna Sadam & 0,597229 & 2 \\
\hline
\end{tabular}

Remiantis pasirinktais kriterijais ir naudojantis SAW metodu, atliktas įmonių rangavimas. Iš 33 įmonių, atrinktos 10 įmonių, kurios pagal SAW metodą, generuoja didžiausią pelningumą ir mažiausią riziką. Pirmoje vietoje - AB Ignitis gamyba, antroje - SIA Tallina Sadam, trečioje - AB Klaipédos nafta. Pagal SAW metodą, nerekomenduojama investicinio portfelio sudaryti iš paskutinèje vietoje esančių įmonių (prasčiausius rangus turinčias įmones) - SIA Silvano Fashion group, SIA Tallinna Vesi ir AB Vilkyškių pieninè.

Antrasis - TOPSIS metodu sudarytas investicinis portfelis. Remiantis šiuo metodu, taip pat atliktas įmonių rangavimas - kuris leido išskirti 10 optimaliausių akcijų, generuojančių didžiausią pelną ir mažiausią riziką.

5 lentelè. Atrinktos akcijos pagal TOPSIS metodą (sudaryta autorių)

\begin{tabular}{|l|c|c|}
\hline \multicolumn{1}{|c|}{ Akcijos } & $\mathrm{P}_{\mathrm{i}}$ & Rangai \\
\hline Apranga & 0,42875 & 6 \\
\hline Eften real estate fund III & 0,50907 & 5 \\
\hline HansaMatrix & 0,78286 & 2 \\
\hline Nordecon & 0,40973 & 10 \\
\hline Novaturas & 0,99935 & 1 \\
\hline PRFoods & 0,41425 & 9 \\
\hline Panevėžio statybos trestas & 0,42177 & 8 \\
\hline SAF Technika & 0,52420 & 4 \\
\hline Tallinna Sadam & 0,65489 & 3 \\
\hline Tallinna Vesi & 0,42800 & 7 \\
\hline
\end{tabular}


5 lentelèje pateiktos 10 geriausių akcijų pagal Topsis metodo skaičiavimus. Pirmoje vietoje, skirtingai nei SAW metodo portfelyje yra AB Novaturas, antroje - SIA HansaMatrix, trečioje - SIA Tallina Sadam. SIA Tallina Sadam įmonė atrinkta ir pagal SAW metodą. Trys prasčiausios įmonių akcijos pagal skaičiavimus yra SIA Silvano Fashion group, SIA Arco Vara, AB Baltika. Lygindami du sudarytus portfelius, matyti, kad SIA Silvano Fashion Group įmone SAW metodo portfelyje yra antroje vietoje, tačiau TOPSIS metodo portfelyje ji yra prasčiausioje trisdešimt trečioje vietoje.

Toliau apskaičiuojama visų akcijų įtrauktų į SAW portfeli ir ị TOPSIS portfeli laukiama pelno norma. Norint išsiaiškinti laukiamą portfelių pelno normą, ją nustatome pagal 14 formulę. Vidutinès įmonių akcijų pirkimo ir pardavimo kainos, apskaičiuojamos remiantis 2008-2018 metų duomenimis. Optimalių investicinių portfelių laukiamos pelno normos pateikiamos 6-7 lentelèse.

6 lentelè. Suformuoto pirmojo portfelio laukiamas pelningumas ir rizika (sudaryta autorių)

\begin{tabular}{|l|c|c|c|}
\hline Akcijos atrinktos SAW metodo büdų & Svoris & Laukiama pelno norma \% & Laukiamas pelningumas \% \\
\hline Ignitis gamyba & 0,1 & 120,2249 & 12,2249 \\
\hline Tallinna Sadam & 0,1 & 0,1401 & 0,0140 \\
\hline Klaipedos nafta & 0,1 & 0,4075 & 0,0408 \\
\hline Energijos skirstymo operatorius & 0,1 & $-2,1099$ & $-0,2110$ \\
\hline Pro Kapital Group & 0,1 & 0,2124 & 0,0212 \\
\hline Telia Lietuva & 0,1 & $-0,5935$ & $-0,0593$ \\
\hline Tallinna Kaubamaja Grupp & 0,1 & 0,3315 & 0,0331 \\
\hline Apranga & 0,1 & $-0,2096$ & $-0,0210$ \\
\hline Novaturas & 0,1 & $-3,7711$ & $-0,3771$ \\
\hline Panevežio statybos trestas & 0,1 & $-0,7245$ & $-0,0724$ \\
\hline Portfelio laukiamas pelningumas & & 11.39 \\
\hline Standartinis nuokrypis & & 3.83 \\
\hline Šarpo rodiklis & & 2.895 \\
\hline Variacija & & 0.129259 \\
\hline
\end{tabular}

Siekiant įvertinti daugiakriterinio vertinimo metodų būdu sudarytus optimalius investicinius portfelius, apskaičiuojamas laukiamas pelningumas kiekvienos akcijos atskirai, tuomet viso portfelio kartu, randamas rizikos lygis t. y. standartinis nuokrypis, apskaičiuojamas Šarpo rodiklis bei variacijos dydis.

Kiekvienai įmonei suteikiamas vienodas 0.1 svoris portfelyje, laikant, kad portfelị sudarys vienodas įmonių akcijų kiekis. Laukiamą portfelio pelningumą galima apskaičiuoti susumavus visų įmonių akcijos svorių ir laukiamų pelno normų sandaugas. 6 ir 7 lentelèse matome dviejų sudarytų portfelių laukiamus pelningumus.

7 lentelè. Suformuoto antrojo portfelio laukiamas pelningumas ir rizika (sudaryta autorių)

\begin{tabular}{|l|c|c|c|}
\hline Akcijos atrinktos TOPSIS metodo būdų & Svoris & Laukiama pelno norma \% & Laukiamas pelningumas \% \\
\hline Novaturas & 0,1 & $-3,7711$ & $-0,3771$ \\
\hline HansaMatrix & 0,1 & $-1,8197$ & $-0,1820$ \\
\hline Tallinna Sadam & 0,1 & 0,1401 & 0,0140 \\
\hline SAF Technika & 0,1 & 1,9651 & 0,1965 \\
\hline Eften real estate fund III & 0,1 & $-0,0837$ & $-0,0084$ \\
\hline Apranga & 0,1 & $-0,2096$ & $-0,0210$ \\
\hline Tallinna Vesi & 0,1 & $-0,1980$ & $-0,0198$ \\
\hline Panevěžio statybos trestas & 0,1 & $-0,7245$ & $-0,0724$ \\
\hline PRFoods & 0,1 & $-1,2145$ & $-0,1214$ \\
\hline Nordecon & 0,1 & $-0,7795$ & $-0,0779$ \\
\hline Portfelio laukiamas pelningumas & & -0.67 \\
\hline Standartinis nuokrypis & & 0.15 \\
\hline Šarpo rodiklis & & -6.63 \\
\hline Variacija & & 0.001567 \\
\hline
\end{tabular}

Pirmojo portfelio, sudaryto iš akcijų, pagal gautus SAW metodo rezultatus, laukiamas pelningumas yra $11.39 \%$. Antrojo portfelio laukiamas pelningumas neigiamas - $0.67 \%$. Daroma išvada, jog šiuo atveju SAW metodo rezultatai pranašesni, ir generuoja pelningesni portfeli nei TOPSIS metodo atrinktos akcijos. Pirmojo portfelio rizikos lygis, apskaičiuojamas standartiniu nuokrypiu gaunamas 3.83, antrojo portfelio rizika gerokai mažesnė nei pirmojo portfelio - $0.15 \%$. Variacijos koeficientas - tai skirtumas tarp didžiausios ir mažiausios 
reikšmés (Nhi et al., 2019). Kuo variacijos koeficientas mažesnis, tuo požymio variacija mažesnė ir atvirkščiai. Taigi pirmojo portfelio variacija - 0.129, tai reiškia, tokia dalimi portfelio akcijų rezultatai varijuoja. Antrojo portfelio variacija mažesnè - portfelio akcijos gana panašios, varijuoja maža dalimi 0,0015 . Taigi, galima teigti, TOPSIS metodo rezultatai generuoja panašesnes akcijas, pagal analizuojamus kriterijus. Galiausiai yra lyginamas ir Šarpo rodiklis, kuris leidžia palyginti investicinio fondo ar kitokio portfelio grąžą virš nerizikingos grąžos, atsižvelgiant ị rizikos lygi (Yufei et al., 2019). Siekiant apskaičiuoti šį rodiklį reikalinga nerizikinga palūkanų norma, kuri bus prilyginama ilgalaikių Lietuvos vertybinių popierių palūkanų normai. Remiantis Europos Centrinio banko duomenimis (2019), ilgalaikių Lietuvos vertybinių popierių palūkanų norma siekia: 0.31\%. Aukštesnès rodiklio reikšmės rodo didesnị optimalaus investicinio fondo patrauklumą. Vertinant šių portfelių Šarpo rodiklius, matome didelį skirtumą. Pirmojo portfelio rodiklis lygus 2,895. Antrojo portfelio patrauklumas pagal Śarpo rodiklį yra neigiamas $(6,63)$. Sis neigiamas skaičius parodo, jog TOPSIS metodo būtų atrinktų akcijų portfelis visai nepatrauklus investuotojui, nors ir rizikos lygis labai žemas.

Ivertinus šiuos du portfelius, galima teigti, jog SAW metodo išskirtos akcijos generuoja didesni pelningumą, tačiau su didesne rizika, jos yra patrauklesnès investuotojui, pagal Šarpo rodiklị, nei TOPSIS metodo būdu išskirtos akcijos. Taip pat TOPSIS metodas išskiria panašiausias įmones ị portfeli nei SAW metodas, o tai nediversifikuoja siekiamo optimalaus investicinio portfelio.

\section{Išvados}

Kiekvienas investuotojas turi balansuoti tarp rizikos ir pelningumo, kad gautų maksimalią grąžą. Optimalus investicinis portfelis yra apibūdinamas kaip portfelis, kuris turi mažiausią riziką esant tam tikram pelningumui arba didžiausią pelningumą esant tam tikram rizikos lygiui. Priklausomai nuo to, kokie portfelio formavimo tikslai, investuotojo charakterio savybès bei prisiimamos rizikos ir pelningumo atžvilgiu, vertybinių popierių portfelis gali būti valdomas dviem tipais: aktyviai ir pasyviai.

Analizuojant daugiakriterinio vertinimo literatūrą, prieita prie išvados, jog analizès, kurios nagrinèja akcijų pelningumą, grynajji pelną, nuosavo kapitalo grąžą ir kitus rodiklius, užima daug laiko ir reikalauja išsamių žinių, ir šios analizès ne visada pasiteisina. Informacija, skirta daugiakriteriniam vertinimui, akcijų atrankoms atlikti yra paini ir interpretuojama dvejopai, taigi akcijų atrinkimas i portfeli yra laikomas kompleksiniu sprendimu. Atsižvelgiant i tai, kad kompleksiškumas auga didèjant akcijų ir kriterijų skaičiui, būtent todèl taikyti daugiakriterinius vertinimo metodus naudinga išskiriant patraukliausias akcijas investuotojui. Taip pat daugiaktiterinio vertinimo metodai yra nesubjektyvūs ir šių metodų pritaikymas leidžia susisteminti informaciją ir daryti nešališkas išvadas dẻl ịmonių patrauklumo ir efektyvumo. Šie metodai leidžia apjungti daugelị skirtingų techninès, fundamentalios ar kitų analizių veiksnius ir ịvertinti kaip vieną kriterijų. Šios priežastys lèmè daugiakriterinių metodų pasirinkimą, sudarant optimalius investicinius portfelius, nei kiti analizès būdai.

Išsiaiškinta, kad investuotojai pirmenybę teikia pelningai veikiančioms įmonèms, kurios generuoja aukštą pelningumą ir mažiausią riziką. Tai patvirtina ir mokslininkai, nustatę, kad akcijos kainos ir akcijos buhalterinès vertès santykis, išmokètos dividendų sumos ir akcijos kainos santykis, grynojo pelno ir pardavimo santykis bei grynojo pelno ir nuosavo kapitalo santykio rodikliai padeda geriausiai apskaičiuoti ir ịvertinti ịmonès padètị, tuo pačiu ir sudaryti optimalų investicinị portfelị. Dèka SAW ir TOPSIS metodų, šie veiksniai buvo sujungti $\mathfrak{i}$ vieną komponentą ir atlinktas daugiakriterinis vertinimas, kuris leido išskirti dešimt investuotojui patraukliausių įmonių akcijų. SAW ir TOPSIS metodai leido sužinoti, kurios akcijos efektyviausios, pagal šešių pasiriktų kriterijų 20082018 metų rezultatus. Tai yra Apranga, Novaturas ir Panevėžio statybos trestas, kadangi šios įmonès išskirtos abiejuose metoduose, aukščiausiose pozicijose.

Ivertinus sudarytus du optimalius investicinius portfelius, pastebèta, jog dauguma SAW ir TOPSIS išskirtų įmonių skiriasi. Trys iš trisdešimt trijų ịmonių pakliuvo ị abu sudaromus portfelius t. y. Apranga, Novaturas ir Panevėžio statybos trestas. Didžiausią pelningumą generuojanti Igtinis gamyba, išskirta tik SAW metode, kuri ir lèmé pirmojo portfelio geresnius rezultatus. Portfelio laukiamas pelningumas didesnis net 17 kartų nei antrojo portfelio, bet atitinkamai ir rizika yra didesnè. Sudarytų optimalių portfelių variacijos taip pat skiriasi - pirmojo portfelio variacija siekia 0,129 , antrojo - 0,0016. Ir šis rodiklis rodo, kad pirmojo portfelio akcijos yra geriau diversifikuotos. Portfelio grąžos ir rizikos santykị atskleidžia apskaičiuotas Šarpo rodiklis, kuris taip pat pirmumą teikia pirmajam portfeliui, kadangi antrojo portfelio Šarpo rodiklis yra minusinis t. y. $-6,63$. Teigiamas rodiklis nusako, kad pirmasis portfelis sugebejo generuoti didesnę grąžą nei nerizikinga investicija, o neigiamas, kad geriau buvo investuoti i nerizikingas priemones. Taigi galime daryti išvadą, kad pirmasis portfelis yra patrauklesnis investuotojui siekiančiam ịgyvendinti užsibrèžtą tikslą. Tuo pačiu galime teigti, jog SAW metodas šiuo atveju yra geresnis, nei TOPSIS, kadangi generuoja geresnius rezultatus investuotojui, nusprendusiam taikyti daugiakriterinius vertinimo metodus. 


\section{Literatūra}

Baltijos šalių vertybinių popierių birža. (2019). https://www.nasdaqbaltic.com/statistics/lt/shares

Basilio, M., de Freitas, J., Kämpffe, M., \& Bordeaux Rego, R. (2018). Investment portfolio formation via multicriteria decision aid: A Brazilian stock market study. Journal of Modelling in Management, 13(2), $394-417$. https://doi.org/10.1108/JM2-02-2017-0021

Betschinger, M. (2015). Do banks matter for the risk of a firm's investment portfolio? Evidence from foreign direct investment programs. Strategic Management Journal, 36(8), 1264-1276. https://doi.org/10.1002/smj.2302

Brazauskas, M. (2014). Daugiakriterinių sprendimų prièmimo metodo taikymas formuojant vertès investicini portfeli. Ekonomika ir vadyba: aktualijos ir perspektyvos, 1(33), 72-81.

Çalık, A., Çizmecioğlu, S., \& Akpınar, A. (2019). An integrated AHP-TOPSIS framework for foreign direct investment in Turkey. Journal of Multi-Criteria Decision Analysis, 26(5-6), 1-12. https://doi.org/10.1002/mcda.1692

Chen, P. (2019). Effects of normalization on the entropy-based TOPSIS method. Expert Systems with Applications, 16(1), 33-41. https://doi.org/10.1016/j.eswa.2019.06.035

European Central Bank. (2019). Long term interest rate statistic for EU Member States. https://www.ecb.europa.eu/stats/financial_markets_and_interest_rates/long_term_interest_rates/html/index.en.html

Freedman, D. M., \& Nutting, M. R. (2015). How to invest, part I: Portfolio strategy. In Equity Crowdfunding for Investors. (Vol. 45(1), pp. 215-222). https://doi.org/10.1002/9781118864876.ch8

Garcia, F., Guijarro, F., \& Moya, I. (2010). A goal programming approach to estimating performance weights for ranking firms. Computers Operations Research, 37(1), 1597-1609. https://doi.org/10.1016/j.cor.2009.11.018

Ghorabaee, M., Amiri, M., Zavadskas, E., Hooshmand, R., \& Antuchevičienė, J. (2017). Fuzzy extension of the CODAS method for multi-criteria market segment evaluation. Journal of Business Economics and Management, 18(1), 1-19. https://doi.org/10.3846/16111699.2016.1278559

Huang, C. F., Chang, B. R., Cheng, D. W., \& Chang, C. H. (2012). Feature selection and parameter optimizationof a fuzzybaseds to ck selection model using genetic algorithms. International Journal of Fuzzy Systems, 14(1), 65-75.

Ishizaka, A., \& Nemery, P. (2013). TOPSIS. In multi-criteria decision analysis. International Journal of Fuzzy Systems. https://doi.org/10.1002/9781118644898.ch8

Yufei, S., Bo, L., Grace, A., \& Kok, L. T. (2019). Uncertain portfolio optimization problem under a minimax risk measure. Applied Mathematical Modelling, 76(1), 274-281. https://doi.org/10.1016/j.apm.2019.06.019

Jayasekara, P., Adelgren, N., \& Wiecek, M. (2019). On convex multiobjective programs with application to portfolio optimization. Journal of Multi-Criteria Decision Analysis, 1-14. https://doi.org/10.1002/mcda.1690

Javid, A. A., \& Tafti, M. F. (2019). Portfolio optimization with entropic value-at risk. European Journal of Operational Research, 279(1), 225-241. https://doi.org/10.1016/j.ejor.2019.02.007

Kalayci, C. B., Ertenlice, O., \& Akbay, M. A. (2019). A comprehensive review of deterministic models and applications for mean-variance portfolio optimization. Expert Systems with Applications, 125(1), 345-368. https://doi.org/10.1016/j.eswa.2019.02.011

Kheradyar, S., Ibrahim, I., \& Nor, F. M. (2011). Stock return predict ability with financial ratios. International Journal of Trade, Economics and Fiance, 2(5), 391-396. https://doi.org/10.7763/IJTEF.2011.V2.137

Kimiagari, A. M., \& Amini, S. (2007). Evaluating quantitatives to ckselection strategies in Tehran stock exchange. Journal of Industrial Engineering International Islamic Azad University, 3(4), 14-23.

Koedijk, K., Slager, A., \& van Dam, J. (2019). Building the investment portfolio. International Journal of Fuzzy Systems, 2(3), 25-37. ttps://doi.org/10.1002/9781119437710

Lietuvos Respublikos Seimas. (2007). Lietuvos Respublikos finansinių priemonių rinkų įstatymas (Nr. X-1024). Valstybės žinios, Nr. 17-627.

Nhi, N. Y. V., Xuezhong, H., Shaowu, L., \& Guandong, X. (2019). Deep learning for decision making and the optimization of socially responsible investments and portfolio. Decision Support Systems, 124(1), 56-68. https://doi.org/10.1016/j.dss.2019.113097

Samaras, G. D., Matsatsinis, N. F., \& Zopounidis, C. (2008). A multicriteria DSS for stock evaluation using fundamental analysis. European Journal of Operational Research, 187(3), 1380-1401. https://doi.org/10.1016/j.ejor.2006.09.020

Springer, P. A. (2011). Diversify your investment portfolio. In D. J. Trump (Ed.), Trump University wealth building 101: your first 90 days on the path to prosperity. https://doi.org/10.1002/9781118258071.ch17

Stanujkic, D., Zavadskas, E., Karabasevic, D., Turskis, Z., \& Keršulienė, V. (2017). New group decision-making ARCAS approach based on the integration of the SWARA and the ARAS methods adapted for negotiations. Journal of Business Economics and Management, 18(4), 599-618. https://doi.org/10.3846/16111699.2017.1327455

Teresienè, D. (2009). Lithuanian stock market analysis using a set of Garch models. Journal of Business Economics and Management, 10(4), 349-360. https://doi.org/10.3846/1611-1699.2009.10.349-360

Zhang, H., Watada, J., \& Wang, B. (2019). Sensitivity-based fuzzy multi-objective portfolio model with Value-at-Risk. IEEJ Transactions on Electrical and Electronic Engineering, 14(11), 1639-1651. https://doi.org/10.1002/tee.22986

Žilinskij, G. (2012). Investiciju portfelio sprendimai (Daktaro disertacija). Technika. https://doi.org/10.20334/2078-M

Žilinskij, G. ir Rutkauskas, A. V. (2012). Akcijų investiciniu patrauklumu paremtas investicinio portfelio sudarymo modelis. Verslas: teorija ir praktika, 242-252. https://doi.org/10.3846/btp.2012.26 


\title{
APPLICATION OF MULTI-CRITERIA METHODS TO COMPOSE \\ INVESTMENT PORTFOLIO OPTIMIZATION
}

\author{
Radvinè SKOBAITĖ, Raimonda MARTINKUTĖ-KAULIENE்
}

\begin{abstract}
Many theories take into account the historical data of financial instruments when investigating portfolio formation. However, in order to obtain a higher return, detailed analysis is required and therefore complex valuation is required for the selection of financial instruments. The paper uses multi-criteria valuation methods for investment portfolio design, which allow to systematize all necessary factors and perform complex valuation. The SAW and TOPSIS methods avoid subjectivity without requiring the determination of significance coefficients for the factors under consideration. The investment portfolio valuation model involves the design of a system of factors, the application of a multi-criteria approach, the valuation and ranking of financial instruments in the analyzed context. In this case, the stocks selected in the SAW approach yielded better results when comparing expected profitability, risk, coefficient of variation and Sharp. The purpose of this paper is to build optimal investment portfolios by applying multi-criteria valuation techniques to SAW and TOPSIS. The following research methods have been applied in the article: analysis of scientific literature, systematization, comparison, analysis of financial reports, statistical data analysis, multicriteria methods SAW and TOPSIS, graphical representation of data.
\end{abstract}

Keywords: investment portfolio, optimization, SAW, TOPSIS, financial instruments, selection. 